\title{
Who Owns Indian Companies? A Decade Of Shareholding Patterns Of Automobile And It Industry.
}

\author{
Vincent Konadu Tawiah ${ }^{1}$, Dr Sakshi Sharma ${ }^{2,}$ Mudaheranwa Benjamin ${ }^{3,}$ \\ Dr Anil Chandok 4 Maniriho Emmy Arsonval
}

\author{
1.M.Com, University of Mysore, Chartered Accountant of GHANA, 2. Assistant Professor, MM U, Institute \\ of Management, MMU Mullana (Haryana) 3. Ph.D Scholars, MM Institute of Management, MMU Mullana \\ (Haryana State ,India),4. Professor MM Institute of Management, MMU Mullana (Haryana) 5.MBA in Airline \\ and Airport Management-Bharathiar University India
}

\begin{abstract}
It is not unusual for entity to derive its ownership and control structure from the culture and traditions of country of origin. It has become cliche that Indian companies are dominated by family ownership in the form of promoters due to the strong family cultural system of the country. Focusing on the Automobile and the IT industry, this paper takes particular look at the shareholding distribution over the last decade ending 2013. Sampling top 10 companies from the industries, a comparative trend, median and mean analysis was conducted within and between the industries. The research reveals that concentrated promoter's ownership is still strong both companies especially in the automobile industry with more than 50\% promoters' shares. Promoters' ownership in the IT industry had steep fall from 57.1\% in 2004 to $45.0 \%$ in 2013. It was known from the study that the automobile industry has more both institutional and individual investors than the IT industry, but the institutional investors' in increasing faster in the IT industry than the Automobile industry. It was concluded that, age of the firm as well as internationalisation of the company have impact on the shareholding patterns. Whiles old companies in the Automobile industry are family dominated ownership in the form of promoters, global companies in the IT industry are less concentrated with promoter's ownership.
\end{abstract}

Keyword: Individuals, Institutional, Promoters, Shareholding pattern.

\section{Introduction}

Raising money for investment for any corporation or business been it small or big is same everywhere. The point of variation among companies is the magnitude of how much to take from a source. The challenge of sourcing an investment or business is how a company wants to spread ownership across. This is very crucial in terms of equity finance where all shareholders have equal rights and ownership in accordance with the number of number of shares they hold.

Although laws and Acts define equity holders as the owners who appoints and vest power in BOD but practically speaking, equity holders are residuary who enjoys or suffers the decision and actions of the BOD.

The components of equity owners of company depends on the categories namely promoter/promoter's group, institutional investors, individuals, government and foreign investors who have shares in the company at a particular time.

The distribution of ownership and voting right among the various categories of holders is term as shareholding pattern of the company. Shareholding pattern demonstrate the control mechanism within the firm company. Who control what and at what level of influence on corporate decision making process.

This current study tracks the pattern of shareholding among the top companies in the Automobile and IT industry for the last decade. It brings to clarity the kaleidoscope of the changing hands of ownership within the categories of shareholders taking into the consideration the growing global nature of Indian companies.

\section{CLASSIFICATION OF SHAREHOLDERS}

The definition and classifications of company's shareholders affects price discovery and helps in validating research and policies. Hence it is essential for uniform categorization of shareholders among all companies. In this line, the Stock Exchange Board of India (SEBI) through its Secondary Market Advisory Committee (SMAC) in 2004 gave out with guidelines on reporting of shareholding patterns by listed companies $^{1}$. For the purpose of the studies some categories have been fused and redefined as follows;

Promoters/promoters group: All individuals, families, corporate bodies or institutions who founded or promoted the company and are presently in control of the company and their relatives. In control means owing more than $20 \%$ in equity of the company. For the sake of this study promoters/promoters group includes both Indian based and foreigners. 
Institutional investors: This category of shareholders are the corporate bodies, partnerships financial institutions banks, insurance companies, mutual funds and venture capitals without any controlling interest. Under this study, the definition of institutional investors includes domestic institutions and state and central government institutions.

Individual investors: Individuals and Hindu Undivided Families (HUF) based in both India and outside. For the study it includes only domestic individuals and HUFs. It excludes Non - Resident Indians (NRI)

Government; Shares held by the Central Government or by any State Government, as a portfolio investment, Shares held by any organization/ undertaking/ enterprise/ institution, which is controlled by the Central Government or any State Government, as a portfolio investment.

\section{Data Collection}

\section{Research Methodology.}

The study is based on secondary data. The main source of data is audited published annual reports of selected companies, journal and articles. 10 listed companies each were selected from Automobile and IT industry in India.

Sampling

The companies were selected based on the National Stock Exchange (NSE) market capitalization as that July 15, 2014. Priority was given companies with Indian origin indigenous companies. The study covers a period of 10years ending 2013 accounting year for both industries.

Data Analysis

The data was analysed using time series trend analysis. To achieve the objective of analyzing the trend in shareholding pattern within and among industries, the mean and median trend analysis of for 10years has been used for study.

\section{BACKGROUND STUDY}

Since the birth of joint stock companies how shares are owned and controlled in terms of shareholding pattern has become a centre of attraction for both the professionals and academician. Most researchers have tried to find out how companies shares are owned by whom across the globe. The Stock Exchange Board of India (SEBI) has focused on creating diversification in shareholding in the Indian market through regulations and other guidelines. SEBI mandates a minimum public float of $25 \%$ for private-owned companies and $10 \%$ for government owned companies. All these efforts are geared towards enhancing investors' protection so as to enable more investors to participate in the capital market.

Adolf and Gardner (1929) studies in modern corporations and private property, one of the premier researches into the field, showed that, there is high spread ownership among American companies.

Even the major shareholder had less than $1 \%$ of ownership. What was much worried was that, although there was rise in institutional investors, but they were not active in the monitoring, governing and functioning of the company.

This conclusion was confirmed by followed up studies by different researchers in Japan and Germany.

Enormous dispersion of ownership led to the rise in the management control and power over companies. This is trend can be observe in the threat of joint stock companies as managers are seen to receiving higher benefits at the expense of owners raising much concern about agency problem and corporate governance.

The predominance ownership concentration nature of Indian companies can be traced back to the days of the British Managing Agencies. (Balasubramanian, 2010, pp. 359-365)

In a different study conducted by Balasubramanian and Ramasway (2014) in to the ownership pattern of NIFTY companies, it was find out that, promoter in domestic private sectors are increasing holdings as well as institutional investors. On the other hand retail/non-institutional shareholders especially individuals recorded a high decrease in holdings. The study was conducted using time series analysis of decade data collected from National Stock Exchange. Some of the findings are;

Concentrated ownership entities marginally decrease from 44 in 2001 to 42 in 2011 of the fifty companies. But the median dominate shareholders has gone up to $56.24 \%$ in 2011 from $42.9 \%$ in 2001 . This confirms the common assertion that concentrated ownership is predominance in India.

It was recorded that there was a steep decline of non-institutional retail shareholding over the decade. This phenomenon was common across the world doing the study period.

NIFTY Junior companies recorded the highest of such decline from $31.21 \%$ in 2001 to $15.88 \%$ in 2011. Institutional shareholding on contrary on other virtually remind constant over the period from 30.31 in 2011 to 30.15 in 2011. 
Who Owns Indian Companies? A Decade Of Shareholding Patterns Of Automobile And It Industry.

\section{Automobile industry}

\section{Analysis And Discussions}

The automobile industry is one of the oldest and dominating industry of the Indian economy. The industry is made of manufactures of all kinds of automobile from two wheelers to heavy duty and trains.

From figure $i$ below, it can be seen from the trend that, promoters hold more than $50 \%$ of ownership in the automobile industry making it high promoter concentrated industry. The other category of shareholders had less than $15 \%$ shareholdings. Which means that, the bulk of the ownership right and control are in the hands of the promoters and promoter group. Individuals and institution hold almost the same percentage of ownership right in the industry which is about $13 \%$ and $14 \%$ respectively. Both category exhibit rise and fall pattern over the period with highest percentage had been $16.1 \%$ in 2011 and lowest $10.8 \%$ in 2013 for institutional investors. Individual investors were high in 2013 giving a percentage of $15.5 \%$ and least in 2006 of $11.4 \%$.

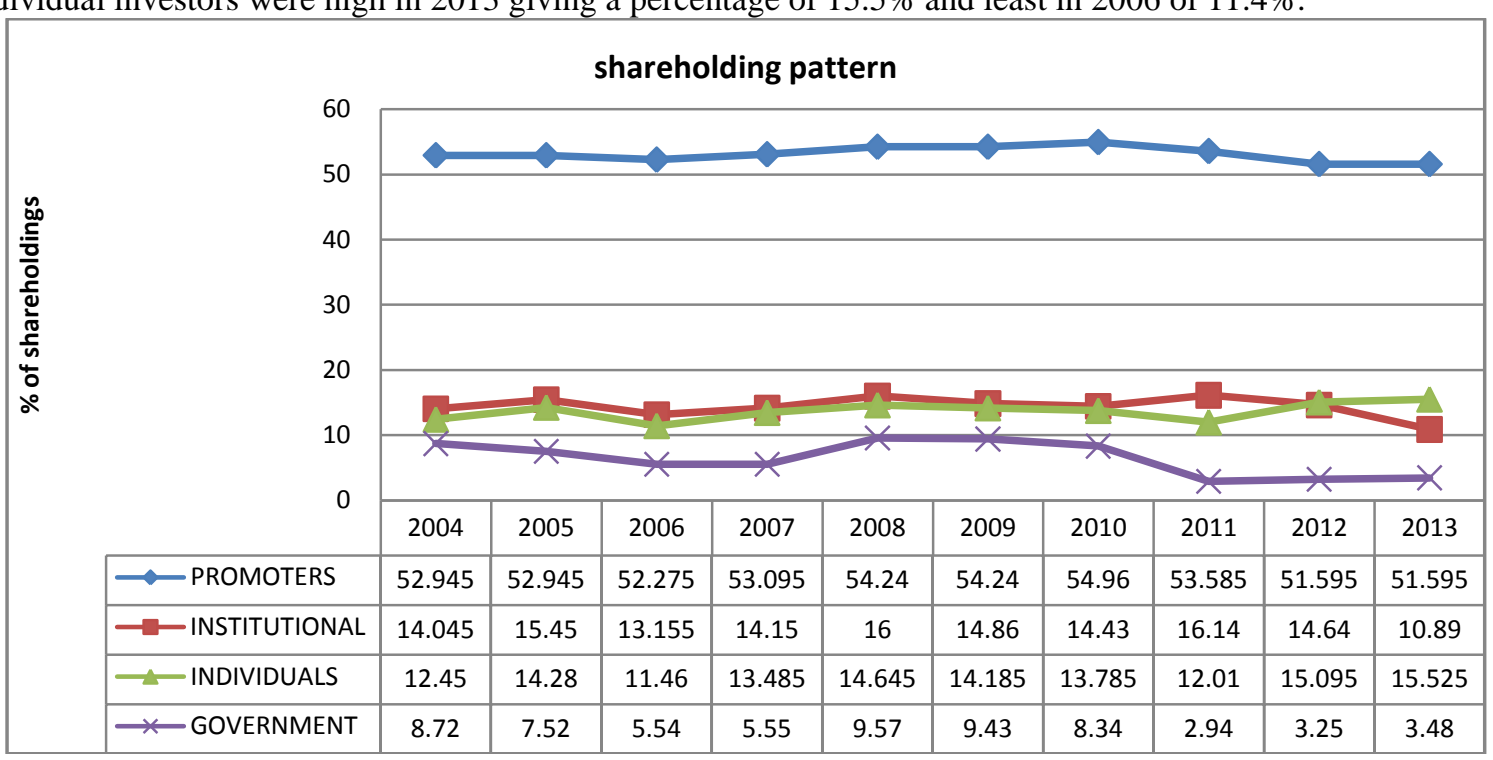

Figure i: shareholding pattern in automobile industry

\section{Promoters in Automobile Industry}

From figure 1 in appendix, it can be seen that whiles the promoters of Bajaj Motors increase their ownership from $46.46 \%$ in 2004 to $60.01 \%$ in 2013 with overall increasing trend over the period. Herocorp , SML Isuzu, Echier and Mahindra have marginally decrease their promoter ownership strength over the decade. Majestic also shows a decreasing pattern from $77.45 \%$ in 2004 to $75 \%$ in 2013.Mahindra and Mahindra has the highest decreasing range of promoter's ownership from $35.65 \%$ in 2004 to $25.98 \%$ in 2013, almost $10 \%$ down. Generally, the promoter shareholding pattern of the automobile industry has not change much over the decade. As it was $52.945 \%$ in 2004 and move to $51.59 \%$, which was about $1 \%$, decrease. This means that promoters still hold about $50 \%$ of shareholding in the Automobile industry. (see figure 1 at appendix)

This confirms to the empirical research that promoter concentrated shareholding of companies in India.

\section{Institutional Investors}

The main players within the domestic institutional investor's category are mutual funds, financial institutions, banks and corporate bodies with financial institutions and banks dominating. From the study most of the automobile companies had less than $4 \%$ mutual fund shareholders. The bulk of the institutional investors were financial institutions dominated by government undertaken. Financial institutions make about $80 \%$ of the domestic institutional investors.

Over the period under study Bajaj Motors, Majestic and Herocop had less than 10\% domestic institutional investors. Mahindra and Mahindra attracted more institutional investors giving it $14 \%$ jump from $23.78 \%$ in 2004 to $37.08 \%$ in 2013 . The company has had an increasing pattern over the period. While SML Isuzu had an increased in the same categories of shareholders from 8.78\% in 2004 to 25.3\% in 2013, Ashok Leyland maintain its institutional investor's shareholding between $22 \%$-24\% over the period.

Institutional investors in Tata Motors lost or gave up their ownership right and investment thereby decreasing from $14.82 \%$ to $8.03 \%$ in 2013 especially from 2009 to 2013 . The study reveals that Escorts had the highest fall in institutional investors from $33.34 \%$ in 2004 to $4.21 \%$ in 2013. 
Who Owns Indian Companies? A Decade Of Shareholding Patterns Of Automobile And It Industry.

Averaging domestic institutional shares in the automobile industry over the decade has been $15-17 \%$ of the total equity of companies. Using median analysis, the shareholding pattern marginally fluctuated around $14.5 \%$ over the period except for 2013 which drop to $10.89 \%$. (see figure 2 in appendix)

\section{Individual Investors}

The individual category is limited to domestic Indian public. There is a contrast pattern among the companies in the individual shareholding pattern. While Bajaj Motors, Tata and Herocorps are showing decreasing trend over the year, Escorts, Majestic Mahindra and Eicher are demonstrating and increasing trend. Bajaj motors had the highest decrease in domestic individual shareholding of about $10 \%$ thus from $27.01 \%$ in 2004 to 16.56 in 2013. This means that individual shareholders are giving up or loosing ownership rights to the other categories like promoter/promoters group.

Tata motors also felt from $12.73 \%$ to $8.44 \%$ over the decade under this category. The graph depicts that more individuals have interest in Escort therefore, the individual have investors has surge in the Escorts to $44.11 \%$ in 2013 from $26.77 \%$ in 2004.

Mahindra and Mahindra on the other hand has less than $10 \%$ individual investor in its ownership structure. TVS, Majestic and Ashok have be experiencing fluctuation in their domestic individual shareholding pattern over the decade under review.

Here again, the average shareholding of domestic individual across the 10 years fluctuated around $15 \%$. The median analysis shows that, this category of shareholders across the companies increase from $12.45 \%$ in 2004 to $15.525 \%$ in 2013. (see figure 3 in appendix)

\section{Government Shareholding}

Government shares include state and central government and its institutions investment in the companies. Out of the 10 companies selected for the study, only five 5 (Bajaj, Tata, Herocorp, Ashok Leyland and TVS) have explicitly indicated government ownership in terms of shareholding in the annual report.

Ashok and Tata have the highest government shareholding of little over $10 \%$ across the decade. Generally government ownership in the automobile industry is decreasing. Government had 2.5\% ownership in Herocorp in 2004, but it drop to $0.68 \%$ in 2013. The same trend applies to TVS which had government ownership of $8.72 \%$ in 2004 and $0 \%$ in 2013. On a whole government ownership drop from $7.95 \%$ in 2004 to $5.26 \%$ in 2013 . The median analysis also confirm the steep fall which is $8.72 \%$ in 2004 to $3.48 \%$ in 2013 .

\section{IT INDUSTRY.}

Although the Information Technology (IT) industry is not as old as the Automobile industry, it has gain global recognition, making the country IT country. The industry hosts all kinds of Information Technologies, software engineering, hardware development, training and services and host of others. The rapid growth of the software engineering segment attracts research hence this study takes into account more of software engineering companies.

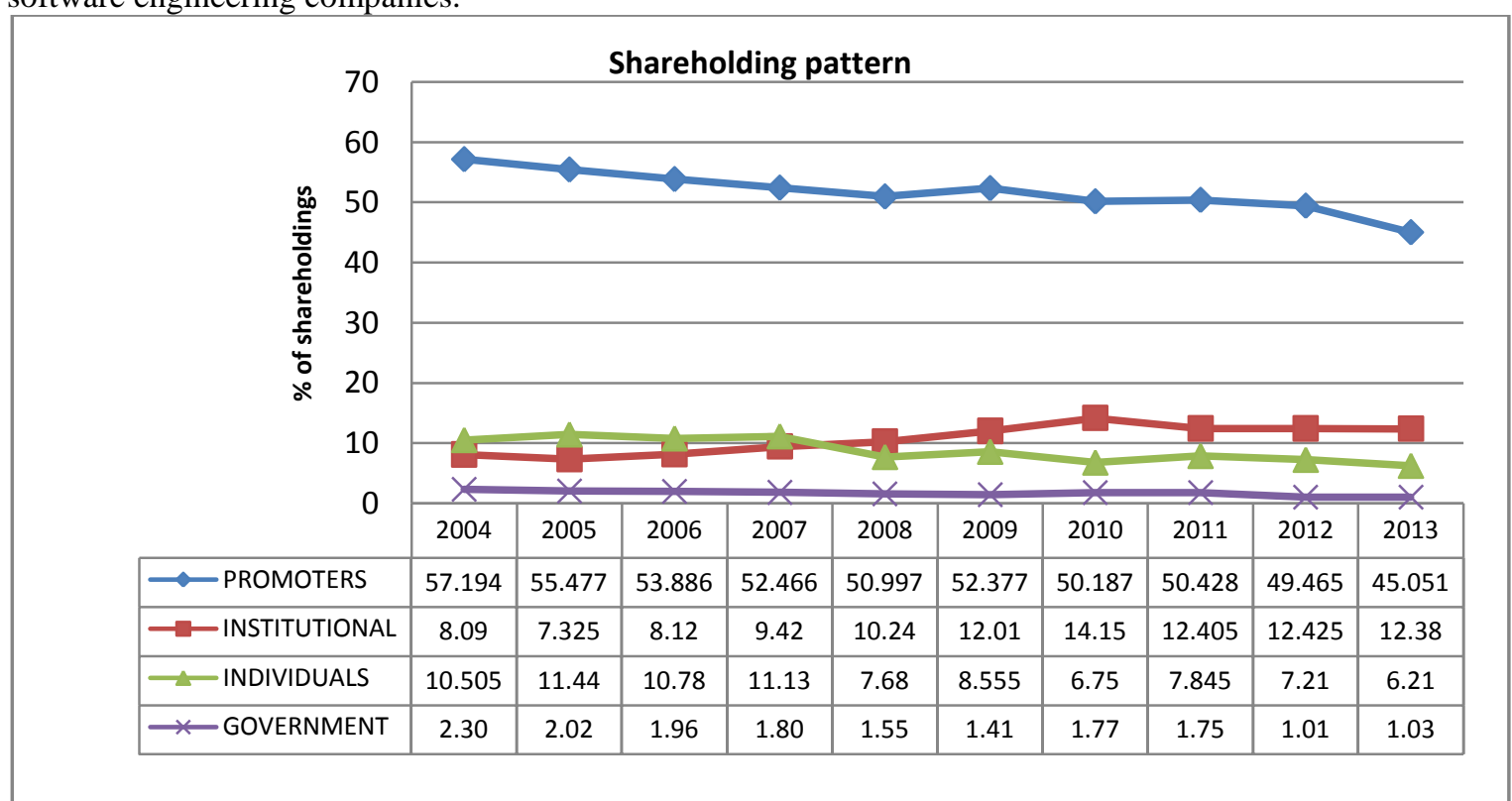

Figure ii: shareholding pattern of IT industry. 
In the above figure ii, although promoter/promoter groups exhibits promoter concentrated ownership of about $50 \%$ ownership right, the trend is falling over the period. The graph reveals that the general trend of promoter shareholding decreased from $2004-2013$.

Unlike the automobile industry where other category holds $15 \%$ shares, institutional and individual investors in the IT industry hold just about $10 \%$ of ownership rights. While the institutional investors are increasing from 2008 onwards, the individual investors were decreasing.

\section{Promoters}

From the study, it was know that, shareholding pattern of promoters and promoters group of INFOSYS has fallen deeply from $26.52 \%$ in 2004 to $16.04 \%$ in 2013 . NIIT has maintained promoter ownership percentage of about $40 \%$ during the period except for 2013 where it drops to $31.29 \%$.

TCS, Zensar, HCL, WIPRO, TechMahindra and INFOTECH promoters are losing or giving up their ownership percentage to other categories of the shareholders. TCS which was highly promoter concentrated of $85.05 \%$ in 2004 dropped to $73.96 \%$ though still concentrated. TechMahindra experience the greatest fall in the promoter ownership form $85.8 \%$ in 2004 to $47.41 \%$ which is almost $50 \%$ decrease over the decade. The promoter ownership of Zensar and Hexware also declined from $64.3 \%$ to $31.05 \%$ and $35.16 \%$ to $27.77 \%$ from $2004-2013$ respectively.

Mphasis on the other hand shows an increasing pattern of $49.75 \%$ in 2004 to $60.49 \%$ in 2013. From the graph it can be seen the highly promoted concentrated company over the decade is TCS with lowest ownership over the years been $73.96 \%$ in 2013 . INFOSYS is the fewer promoters concentrated with ownership pattern less than $20 \%$ across the period.

Generally the promoter and promoter group shareholding pattern has be declining over the period from 57.025 in 2004 to 45.051 in 2013. Meaning that, the IT sector is experiencing dispersed ownership away from promoters. (see figure 4 in appendix)

\section{Institutional Investors}

While the pattern of promoters ownership is falling, the institutional pattern is increasing but at a marginal rate of about $2 \%$. Although NIIT had a jump in its domestic institutional investors from 19.97\% to $27.28 \%$ in 2006 and $25.05 \%$ in 2012, the percentage dropped to $19.99 \%$ in 2013 same as 2004 .

Over the decade, INFOSYS attracted more domestic institutional investors from $7.78 \%$ in 2004 to $17.11 \%$ in 2013 which is directly opposite of the pattern of promoter ownership.

Among the IT companies under review TechMahindra seem to be on top of their game in terms of attracting institutional investors. The percentage of domestic institutional investors rose from $2.4 \%$ in 2004 to $18.31 \%$ which is almost $1000 \%$ increase. Zensar also had good share of the boom in the institutional investors' shareholding as it increase to $14.09 \%$ in 2013 from 5.03\% in 2004.

Although WIPRO also increase in domestic institutional shareholding, it is not as much as TCS and Zensar. Meaning WIPRO attracted 2\% extra institutional investors over the decade. Also WIPRO has the least institutional investors in the IT industry. HCL and Hexware move around the same percentage of domestic institutional investors over the decade.

Domestic institutional investors have been withdrawing or giving up their investment in both Mphasis and INFOTECH as witness in their declining pattern over the 10years period. Mphasis which had $29.4 \%$ institutional investors in 2004 lost to the tune of about $21 \%$ bringing them down to $8.69 \%$ in 2013 . About $7 \%$ of ownership was lost from institutional investors in INFOTECH.

From the analysis it was observed that 8 out of 10 companies attracted institutional investors, with TechMahindra attracting the highest among all and Mphasis showing decreasing ownership under the category.

The general phenomenon in the domestic institutional investors indicates that, more institutional investors are getting attracted to and investing in the IT industry. Although the average trend shows a marginal increase of $1 \%$ over the period the median analysis depicts $4 \%$ increase from $8.09 \%$ in 2004 to $12.38 \%$ in 2013 . (see figure 5 in appendix)

\section{Individual Investors}

The domestic Indian Public don't seem much interested in the IT sector as compared with the Automobile sectors. From the study, almost all companies with exception of Zensar shows a declining pattern of domestic Indian public ownership over the period of study. Most of the declining trend is at marginal rate of $2 \%$ per year. Here also it was observe that, the promoter concentrated ownership trend of Mphasis has affected the individual shareholding as it did with the institutional shareholding. The individual shareholding dropped from $12.65 \%$ in 2004 to $2.68 \%$ in 2013 . It can be seen that both the institutional and individual shareholders are withdrawing maybe because the promoter concentration nature of the companies or promoters are entrenching their control over the company at the expense of both institutional and individual investors. 
Directly opposite of Mphasis pattern is Zensar Company. The shareholding pattern in Zensar signals dispersion over the years. While the promoters are losing or giving out ownership rights, the institutional and individual investors are increasing their ownership rights over the decade.

While promoters' ownership dropped from $64.5 \%$ to $31.05 \%$, individual and institutional investors increase from $9.85 \%$ to $13.13 \%$ and $5.03 \%$ to $14.06 \%$ respectively.

WIPRO, TCS and INFOSYS had marginal decrease of $1 \%$ in individual shareholding pattern from 2004-2013. INFOTECH also experience a similar pattern over the period.

From the analysis it was observed that, increasing pattern of institutional investors was not only driven from the promoters/promoter group. They also gain some ownership form individual category of shareholders. The individual shareholders pattern decrease by $50 \%$ thus $6.55 \%$ in 2013 from $12.4 \%$ in 2004 .

The averages of the selected companies over the decade shows a less than $1 \%$ decline in the shareholding from $9.663 \%$ in 2004 to $8.06 \%$ in 2013 with fluctuation in between the years. The highest recorded individual ownership was $11.853 \%$ in 2007 with $8.064 \%$ been the least in 2013 .

The median analysis also proof that the individual shareholding in the IT companies has decline over the period from $10.50 \%$ in 2004 to $6.21 \%$ in 2013 . But the decline was much felt from 2008 to 2013 . There was almost constant percentage from 2004 to 2007.

\section{Government}

Unfortunately government don't have holdings in most of the IT companies. Government group means central and state government institutions and its agencies. Out of the 10 selected government has holding in only three 3 companies (NIIT, TCS and Hexware). Even with that its holding is less than 5\% in any of them.

The company with highest government shareholding is Hexware which was $4.96 \%$ in 2004 and reducing over the decade to $1.55 \%$ in 2013 . WIPRO had records of government ownership from 2001 (1.08) to $2009(0.07 \%)$ but no records from 2010 to 2013.

Great companies like INFOSYS and TechMahindra does not have any record of government ownership over the period.

None of companies have any increasing pattern of government ownership over the period. This means that government has small shares across the IT industry which is even decreasing.

Although the automobile and IT industry have similar features in terms of government holdings, that is small and decreasing ownership, the automobile has more government ownership than IT sectors (automobile $8.72-3.48 \%$ and IT $2.3 \%-1.03 \%$ )

\section{COMPARISON BETWEEN THE AUTOMOBILE AND IT INDUSTRY}

It was found from the study that, both the promoters/promoters group in the IT and Automobile industry had $52 \%$ of the shareholding of their company. At the beginning of the decade while the promoter shareholding of the IT industry was falling from 57.1\%, the Automobile industry remain unchanged around $52 \%$. Again in the middle of the decade from 2007-2011, Automobile industry experienced marginal increase from $52 \%$ to $54.9 \%$ but the IT industry continued to fall from $52.4 \%$ to $50.4 \%$. Both industries decrease from 2011 - 2013 but the decrease in the IT sector was more than the automobile industry.

Under the institutional investors category of shareholding both industry had almost equal percentage of $14 \%$ in 2010. While the IT industry shows an increasing pattern from $2005-2010$, thus from $7.32 \%$ to $14.1 \%$, the Automobile industry was fluctuating around 14\% during the same period. The Automobile industry experience a steep fall from 2011 - 2013 while the IT industry remains unchanged around 12\%. From the analysis it was known that the automobile industry have more institutional investors than the IT sectors but the automobile pattern is not stable indicating more of decreasing pattern. The IT pattern signals potential of high institutional investors in the future.

Unlike the domestic institutional investors' pattern where the IT industry is increasing, under the individual group, it is decreasing while the automobile industry is increasing. Here also the automobile industry has more individual shareholders that the IT industry, while the shareholding pattern of the automobile industry is more than $11 \%$ over the period, the IT had less than $10 \%$ during the same period. After 2006 where both almost equal, the automobile industry was increasing and the IT industry was declining.

\section{FINDINGS}

Institutional investors are increasing in the IT industry because of its green nature and promising it is to the Indian Economy. The increasing pattern from 2005 was due to the fact that Indian IT gain grounds globally around that period. Mutual funds have investment in almost all the companies of the study but their ownership is not encouraging, less than $3 \%$ in most cases.

The automobile sector still has more institutional and individual investors than the IT industry because it is old and mature with good dividend payout. It is more secure and less risky as compared with changing 
nature of the IT industry. individuals are not much attracted to the IT sector as shown from the analysis because it is risky and grey area with much reinvestment and less dividend payout.

Companies with high promoters' concentration in both industries were family controlled companies like Bajaj Motors, Tata Motors and TCS.

There was little dispersion of ownership from promoters in the IT industry because most of them are international companies with global presence; hence they are playing along with the other counterpart in USA, Europe and other countries. This can be seen in companies like INFOSYS and TCS which is a world brand showing decreasing promoter ownership pattern.

Generally government shareholding is more in the automobile industry than the IT industry because of the long years of existence. This ownership has been there since independence in an attempt to help built an industrial country. The IT is a young industry which dominates after the LPG encouraging privatization than government support.

Both industries are dominated by high promoters shareholding rights over the decade because most companies are family succession controlled.

Family promoter controlled companies is very common in the automobile industry than the IT industry, because most promoters in the IT industry are institutions while individual and family dominates the automobile industry.

Both institutional and individual investors are gaining grounds in ownership in the Automobile and IT industry because of the efficient secondary market. Ownership pattern is gearing towards dispersion rather than the traditional concentrated nature.

The IT industry is less promoter concentrated in terms of shareholding and ownership right than the Automobile industry.

\section{Conclusion}

There is no perfect shareholding pattern for any industry or country. There is no possibility of two companies across any reference term to have same shareholding pattern.

Nonetheless, the study into the shareholding pattern is imperative for the type of corporate control and governance of the company/industry. Furthermore, shareholding pattern indicates the future growth of the company such as takeovers and mergers. It is not uncommon to find no or few hostile and contested takeovers and mergers in Japan as compared to other countries like USA and Europe. Japanese traditional pattern of cross shareholding and legal restriction makes it difficult if not impossible for such transactions.

\section{Reference}

[1]. Balasubramanian and Ramasway (2014). Ownership Trends in Corporate India (2001-2011): Evidence and implications, National Stock Exchange (NSE) Working Paper. NSE, New Delhi, India

[2]. Balasubramanian, N. (2010). Corporate Governance and Stewardship: Emerging role and responsibilities of corporate boards and directors. New Delhi: Tata McGraw Hill.

[3]. Balasubramanian, N. (2013). Strengthening Corporate Governance in India: A review of legislative and regulatory initiatives in 2013. Indian Institute of Management Ahmedabad Working Paper. Indian Institute of Management Bangalore, Centre for Corporate Governance and Stewardship (Forthcoming).

[4]. Vincent K. T and Cho Kien B.(2014) Dividend Pattern of Automobile and IT Industry of India; Pre And Post Global Crisis Analysis. Compendium of Papers (E-book) (forthcoming)

[5]. Jain, Tarun, Corporate Shareholding Pattern: An Analysis of the Changing Perspective in the Indian Capital Markets (December 1, 2006). Available at SSRN: http://ssrn.com/abstract=1087394 orhttp://dx.doi.org/10.2139/ssrn.1087394

[6]. http://sebi.gov.in/resource/guidelines access on $15^{\text {th }} \mathrm{July}, 2014$

[7]. http://indiacorplaw.blogspot.in/2014/04/a-study-on-ownership-concentration-in.html

[8]. $\quad$ http://www.iimb.ernet.in/research/sites/default/files/WP\%20No.\%20419 0.pdf 
Who Owns Indian Companies? A Decade Of Shareholding Patterns Of Automobile And It Industry.

APPENDIX; GRAPHS AND FIGURES

Figure 1 Promoter's shareholding pattern in Automobile industry

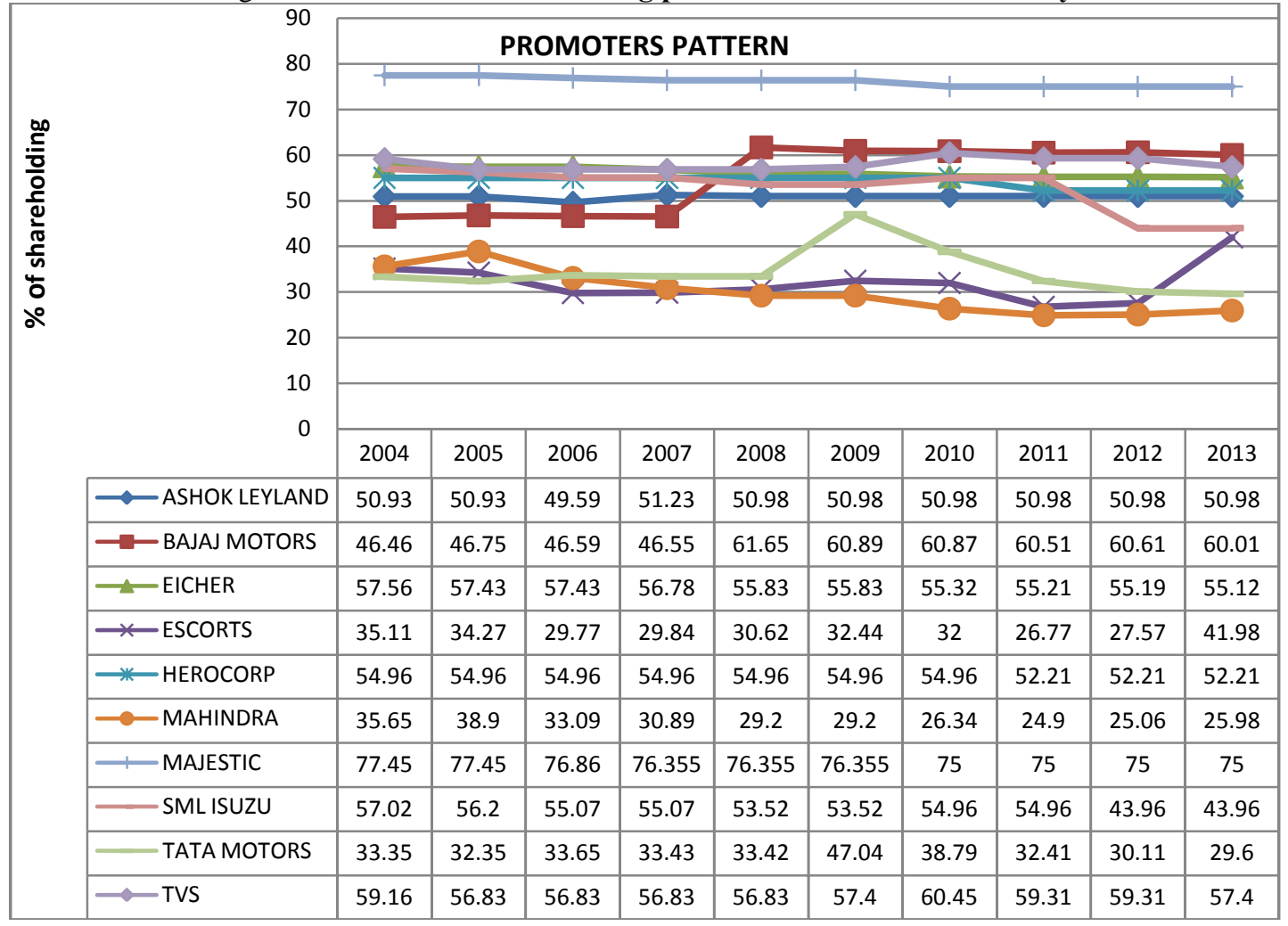

Figure 2: Institutional shareholding patterns in Automobile Industry

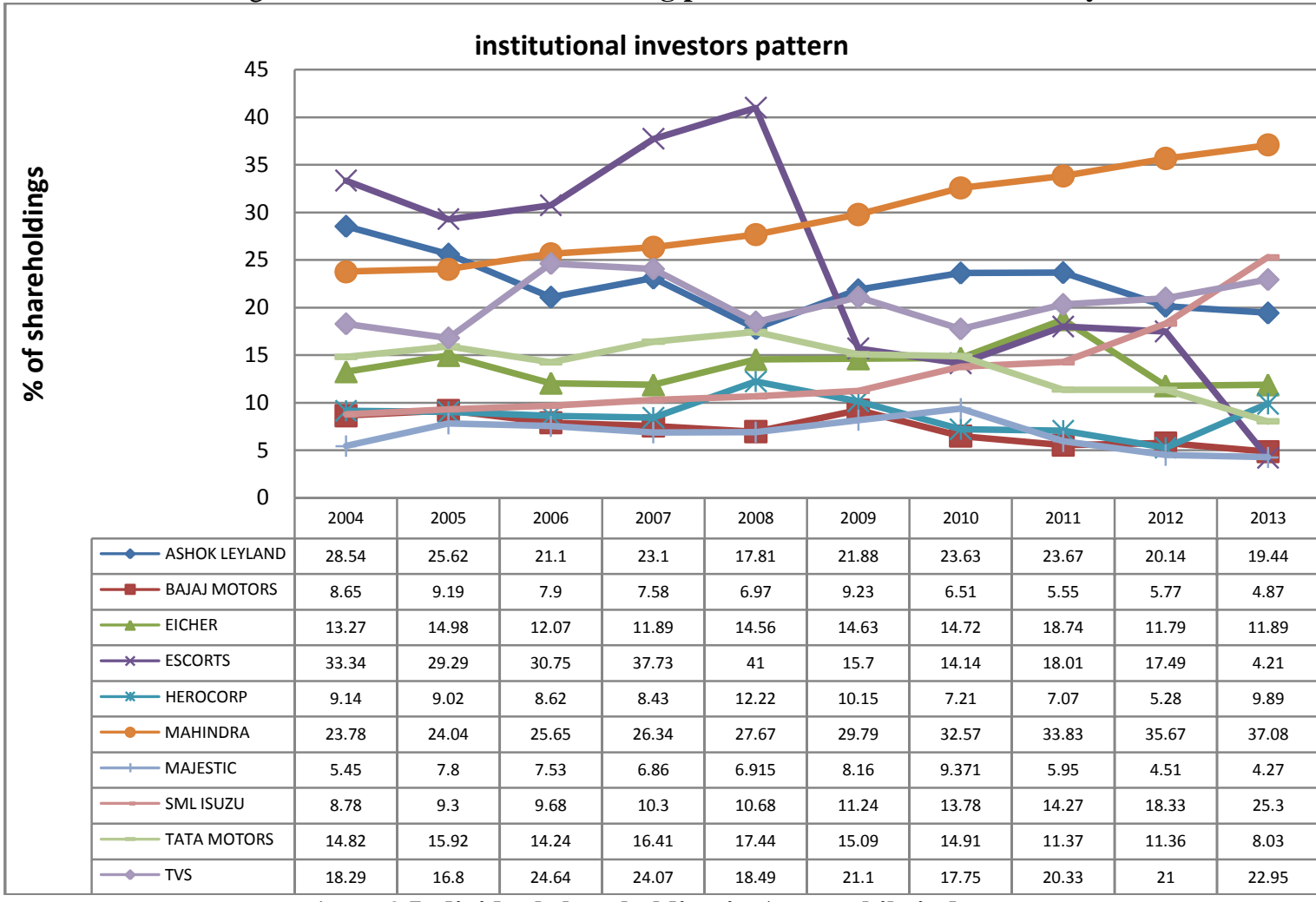

Figure 3 Individual shareholding in Automobile industry 
Who Owns Indian Companies? A Decade Of Shareholding Patterns Of Automobile And It Industry.

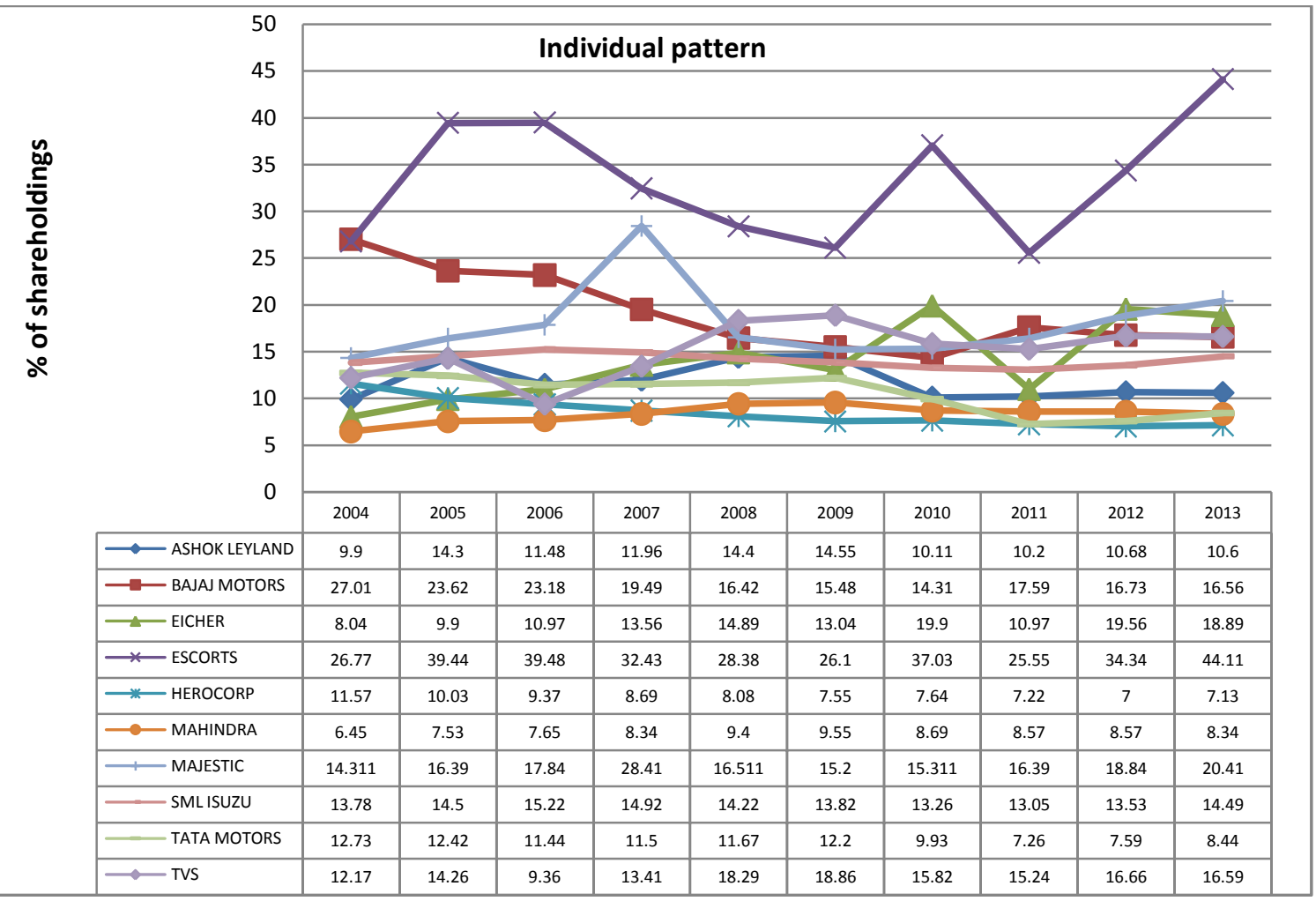

IT SECTOR

Figure 4; Promoters' shareholding patterns in the IT industry

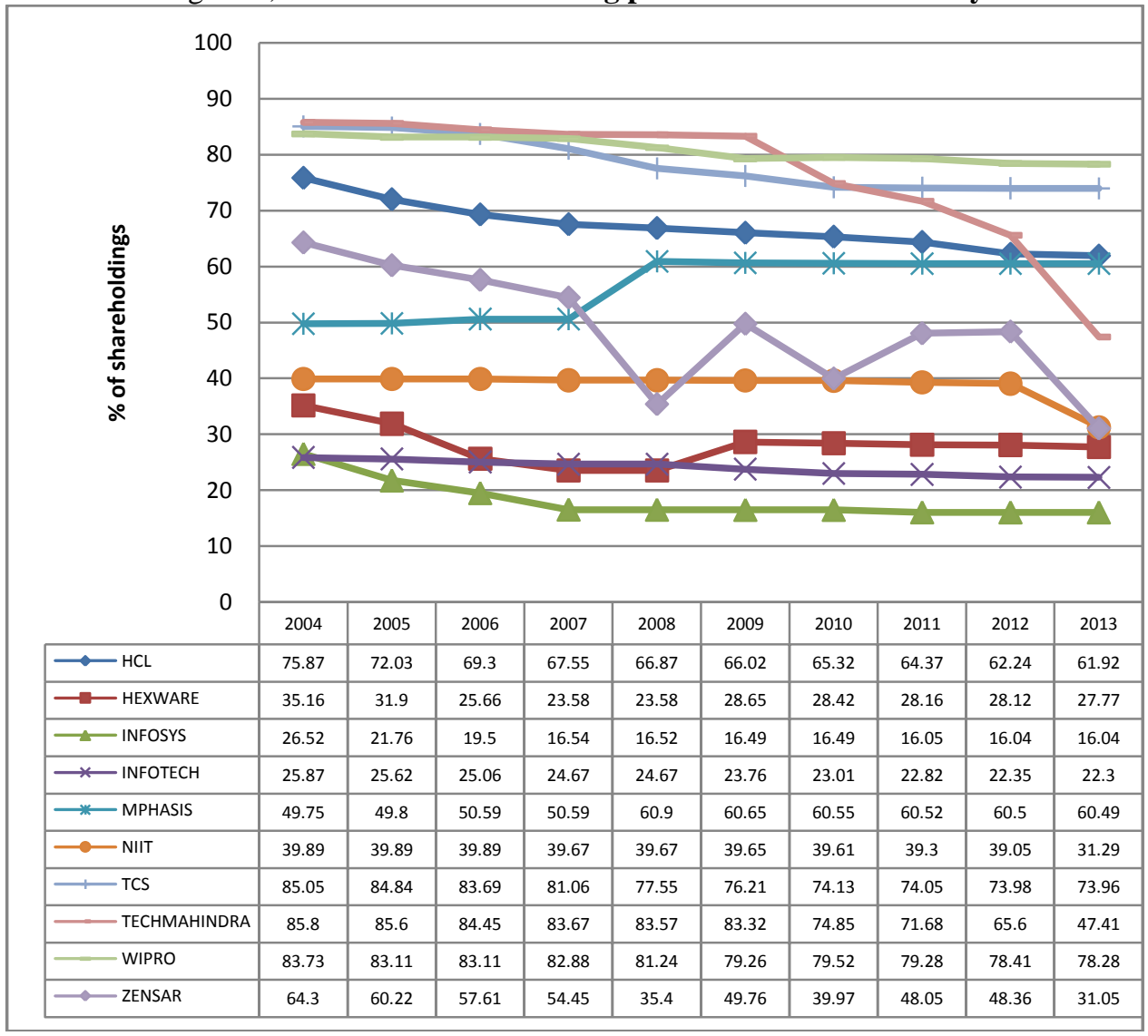

Figure 5; Institutional shareholding pattern in the IT industry 
Who Owns Indian Companies? A Decade Of Shareholding Patterns Of Automobile And It Industry.

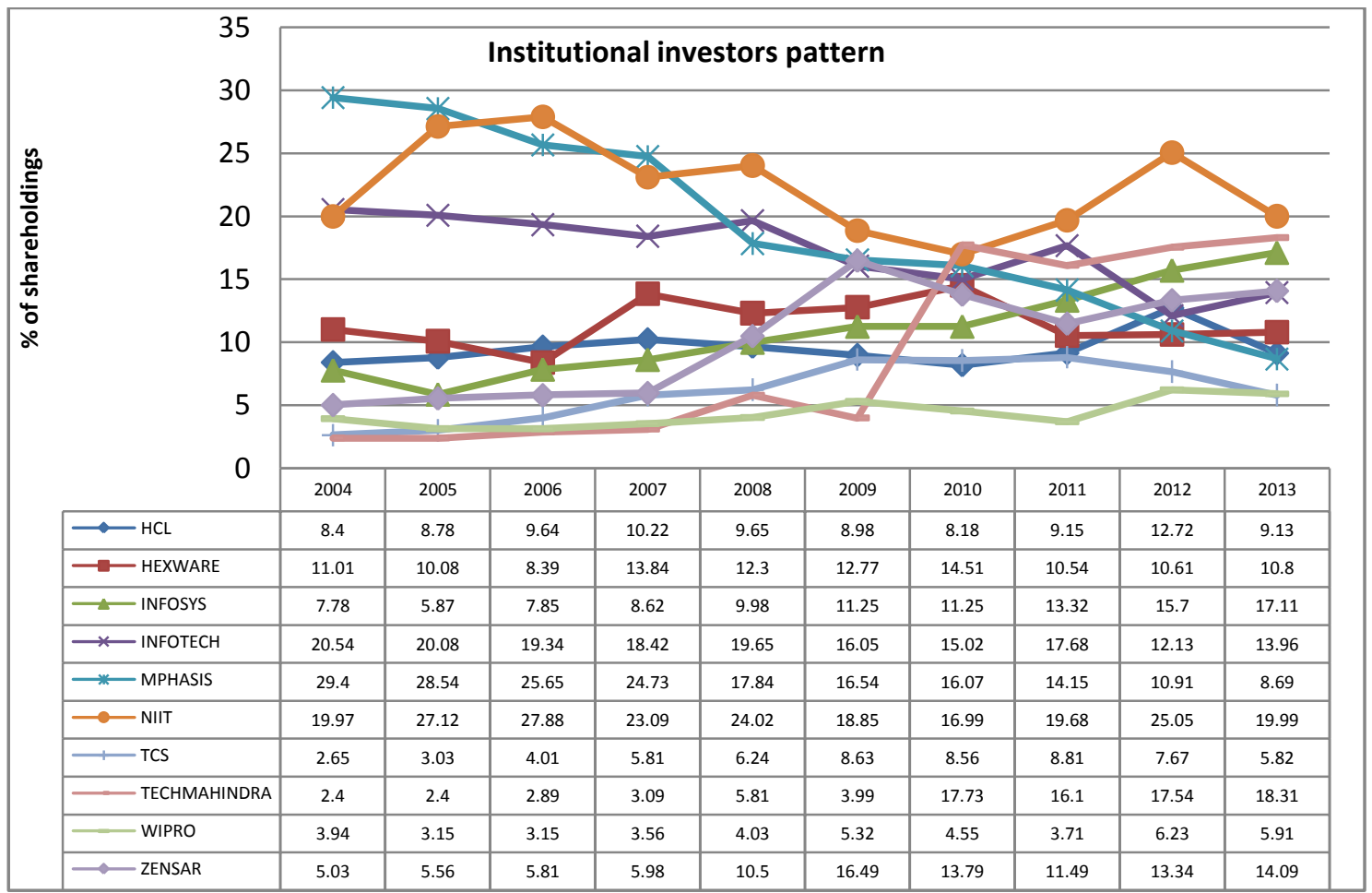

Figure 6: Individual shareholding patterns in the IT industry.

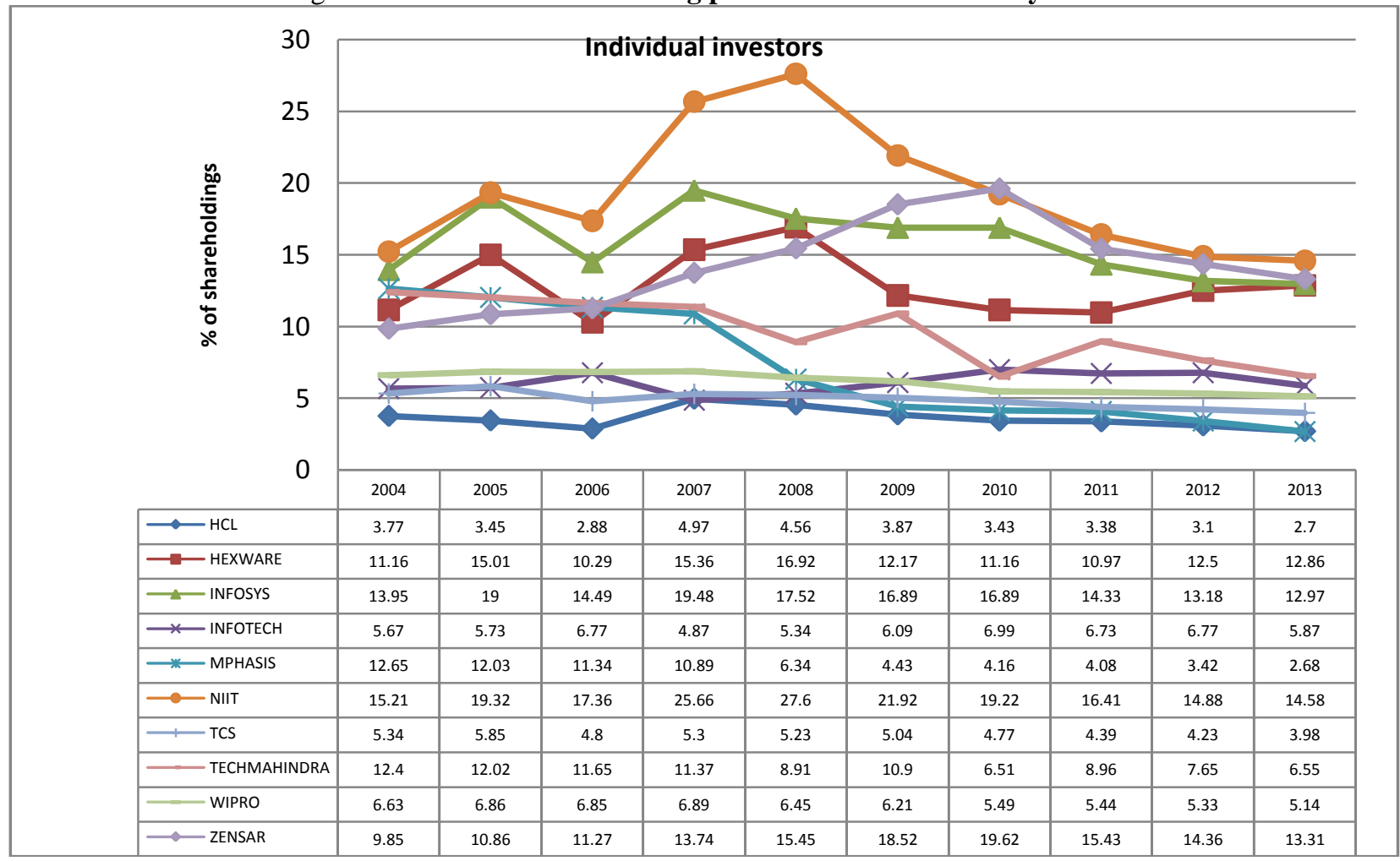

